\title{
Environmental Ethics and Environmental Governance for Security in Africa
}

\author{
Mark Omorovie Ikeke ${ }^{1}$
}

\begin{abstract}
The paper argues that an important aspect of security is environmental security. Without environmental security every other form of security is impeded. There need to be effective environmental governance if there is to be stable environmental security. The paper equally argues that environmental governance should be based on non-anthropocentric environmental ethics. Environmental governance is here understood to imply bringing human and governmental policies and legal frameworks to bear on the management of environmental resources. All over Africa there are a lot of environmental problems such as resource conflicts, climate change, desertification, deforestation, gas flaring, etc. These problems have to be eradicated for the good of the biotic community. This is why the paper is advocating for non-anthropocentric environmental ethics. The paper uses critical hermeneutic/analytic methods to examine the issues. The paper concludes that environmental governance informed by non-anthropocentric environmental ethics is a quintessential for security of lives/ properties in Africa.
\end{abstract}

Keywords: Environment, ethics, security, governance, environmental ethics, environmental security, environmental governance, and Africa.

\section{Introduction}

The traditional-statist understanding of security has long been transcended. Security is no longer simply the stability of the nation or state or of those in power. Security is not simply military ability of the state to defend herself against internal and external aggressions. It is not simply the absence of violent conflicts and wars. It is much more and includes the total well-being of the entire people of the nation, state or country. Security includes peace, prosperity, provision of food and water, wellbeing, access to the good life and the amenities that ensure that good life, safeguarding of the human rights of the citizens, and so forth. It is also inclusive of the preservation of the environment and environmental sustainability. If the environment is degraded and devastated, the lives and wellbeing of the people are endangered. Rightly many human rights' instruments now include right to a safe and healthy environment as fundament to the people enjoying peace, life, and happiness. The Organization of African Unity (1981) affirms that: "All peoples shall have the right to a general satisfactory environment favourable to their development" (art 24). The United Nations (2007) enunciates that indigenous people have the right to the protection and conservation of their environment.

The United Nations in the Millennium Development Goals and subsequently in the Sustainable Development Goals emphasized environmental sustainability and 
protection as a goal that governments must meet if they are to fulfill the purpose why they exist. A government that does not protect the environment, and manages it in a sustainable manner to meet the needs of present and future generations; and for the wellbeing of the entire ecosystems is failing in a key duty of government. This is why it is important for every government in Africa and elsewhere to foster and practice environmental governance. Obi (2001) has cited authors such as Speth, Brook, Renner, Brown, Leach and Mearns, Hyden to show that environmental challenges have implications for global security. He argues from their insights that issues of poverty, economic crisis, drug-trafficking, migration, globalization are all included in security.

Environmental governance for it to be effective should be grounded on sound environmental ethics. The purpose of this paper is to call for a sound environmental ethics in environmental governance for security in Africa. The paper adopts critical hermeneutic and analytic methods to examine the issues in the paper. The procedure here is to do some conceptual clarifications and analysis, examine the state of environmental governance in Africa, state the need for environmental ethics and propose an environmental security ethics for Africa. When this has been done, the paper will make some concluding reflections.

\section{Conceptual Clarifications and Analysis}

The following terms ground this paper. They are environment, ethics, governance, and security. Environment refers to the totality of everything that surrounds an organism or totality of all of nature. Micheals (2004) says it is "the sum of all external conditions and influences affecting the development and life of an organism" (p. 71). For the United Kingdom (1990), the environment is inclusive of water, air, land and the built environment. Ethics on the other hand is the systematic or critical study of what makes for right or wrong human behaviours or conducts. Ethics studies the basis or norms for morality. Environmental ethics affirms that human conducts or behaviours with respect to the natural world or environment are also subjects of ethics. It is not only what humans do to their own fellow human beings that counts. Human behaviours with regard to the natural world can be ethical or unethical. Rolston (1998) who is considered to be one of the foremost founders of environmental ethics enunciates that humans must live with reference to the earth. He argues that humans are part of the earth and they live in the earth. There is need for a naturalized ethics in which humans know that they have a responsibility towards nature, he avers. Schweitzer (1949) rightly observes that:

The great fault of all ethics hitherto has been that they believed themselves to have to deal only with the relations of man to man. In reality, however, the question is what is his attitude to the world and all life that comes within his reach? A man is ethical only when life, as such, is sacred to him, that of plants and animals as that of his fellow men, and when he devotes himself helpfully to all life that is in need of help........ The ethic of the relation of man to man is not something apart by itself: it is only a particular relation which results from the universal one. (pp. 158-159)

DesJardins (2006) states: "In general, environmental ethics is a systematic account of the moral relations between human beings and their natural environment. 
Environmental ethics assumes that moral norms can and do govern human behaviour towards the natural world. A theory of environmental ethics, then, must go on to explain what these norms are, to whom or to what humans have responsibilities, and how these responsibilities are justified" (p.12).

It is the same point that Curry (2006) argues for when he writes that: "The subject is ethics, or, put at its simplest, the question of how one should live and act. In particular it is a relatively new subject called ecological ethics. In this view, ethical questions can no longer be restricted to how to treat other human beings, or even animals, but must embrace the entire natural world" (p. 1).

For the term, "environmental," it is an adjective and has to do with the environment. It can be used to qualify something in relationship to the environment. And so people can speak of environmental ethics, environmental governance, environmental sustainability, environmental peace, etc. Here the paper is concerned with environmental governance. Institute of Governance (2019) says that governance deals with how power is shared in a society or groups and used to take decisions for that group. Tamayao (2019) notes that governance has to do with the exercise of political power for the common good of the citizens. Governance is the exercise of power to achieve the goals and reasons why government is set up by the people. In many democratic societies, the exercise of this power is through the executive, legislative and judicial arms of governments. The legislature makes laws; the judiciary interprets the law and the executive implements and leads the society.

In speaking of environmental governance, it is implied that one of the essential functions of governance or government is to ensure there are proper rules and regulations in the use of the natural resources and even human resources of the state or given society. That the use of the natural and environmental resources of the state is not just left to the whims and caprices of individuals. There are laws that are well implemented and equally supervised. Some of the environmental problems that you find so common in the African continent are as a result of poor environmental management. Some of these problems will be noted later on. The International Union for Conservation of Nature says that the priorities, goals with regard to natural resources management are carried out through environmental governance rooted in appropriate legal framework. For Ramutsindela and Büscher (2019) the response of the state and other groups to environmental challenges constitutes environmental governance.

The paper is concerned with environmental ethics, environmental governance and security in Africa. Now that the above terms have been clarified, what then is security? Today, the term security has acquired a broader meaning. It is no longer just national security of the territorial integrity of the state, or state security and/or even massive acquisition of military weapons. It has to do with the provision and access to the good life and basic amenities for the citizens. Security includes food security, health security, educational security, environmental security, etc. It involves the peace and wellbeing of the people. Fage (2007) notes that defining security in terms of national security is a minimalist approach that lays emphasis on the survival of the state which includes its values, peoples, territory, and institutions. Maximalist school, he says emphasizes a holistic meaning of national security. In this school, Fage (2007) says there are those like Jordan and Taylor who aver that national security includes protecting the state by means 
of economic and political interest and not just the nation and territory. Still on this school, he opines further that Oberg and Wilberg have argued that security must involve the people's lifestyles, cultures, identity, freedom and protection of nature. It also includes their having food, clothing, housing, health, education, they note. Security is a holistic package. It involves every dimension of the people's lives. It also involves relationship of one state to another. Citing Buzzan, Fage (2007) propounds:

The concept of security binds together individuals, states and the international system so closely that it demands to be treated in a holistic perspective. Although some sense can be made of individual security, national security and international security in their own right, a full understanding of each can only be gained if it is related to the other two. Attempts to treat security on any single level invite serious distortions of perspective. (p.123)

One of the cardinal goals of this paper is to note that a major part of security is environmental security. Obi (2001) states that environmental security concerns ending the threats or contradictions emanating from the human interactions with the natural environment. Humans should interact with the environment in a sustainable manner. Environmental security cannot be separated from environmental governance. If the environment in which the people are to live and pursue happiness, liberty and their civic freedoms is polluted, degraded, devastated and compromised; it will create health hazards for them. Their lives will be insecure. There is no true security without environmental security. This is why there is need for effective environmental governance rooted in an authentic environmental ethics.

\section{The State of Environmental Governance in Africa}

The state of environmental governance in Africa leaves much to be desired. It should be noted that not every aspect of environmental governance can be examined here. There is so much negligence of the natural environmental situation in Africa. Many of the environmental problems in the continent could be averted or abated if there was strong and effective environmental governance. Laws and regulations about the environment are made but poorly implemented. Environmental regulations flouted and nobody is brought to book. In Nigeria, there are so many environmental agencies and laws. With regard to gas flaring for instance the federal government had regulated for the stopping of gas flaring in the Niger Delta but till date it continues unabated. The oil multinational companies that operate in the region hardly obey environmental laws. Oil spillage continues in the Niger Delta almost on daily basis. Oil companies respond poorly and slowly to reported cases of oil spillage. Nigeria has many environmental agencies and laws. They include: Federal Environmental Protection Agency Act of 1988, National Environmental Protection (Effluent Limitation) Regulations, and National Environmental Protection (Pollution Abatement in Industries and Facilities Generating Wastes) Regulations; and National Environmental Protection (Management of Solid and Hazardous Wastes) Regulations, Environmental Impact Assessment Act of 1992 (EIA Act), and Harmful Wastes (Special Criminal Provisions etc.) Act of 1988. Yet with all of 
these there are still many environmental problems in Nigeria because the laws are poorly implemented.

Natural resources in African countries are pillaged, plundered and stolen with impunity. All through Africa, countries that are rich in natural recourses have faced or are facing civil wars. Rebels and government in places like the Democratic Republic of Congo and some other states in eastern Africa have polluted the land and oceans with blood as thousands are killed to secure diamond and other mineral resources. In some places like the Democratic Republic of Congo, the presence of the government is not even felt in many places. And so government has no environmental governance in those areas. In places like Sierra Leone, Liberia, Angola wars have been fought over natural recourses. Ribot and Veit (2001) note that more than 400 million of people in SubSaharan Africa are suffering from extreme and dehumanizing poverty in spite of her enormous wealth. Related to this they note that more than 60 percent of the land of the continent is degraded from industrial and agricultural activities.

There is poor environmental management all through the continent. Institute for Security Studies (2009) notes that: "Burgeoning challenges in Africa are linked to environmental insecurity and the development catastrophe, and include poverty, water scarcity, degradation and inequitable distribution of natural resources, loss of arable land, food insecurity, coastal degradation and wetlands intrusion." This Institute avers further that: "These have posed (and continue to pose) great institutional challenges in Africa. These problems are intricately intertwined and compounded with population growth and migration which has led to unanticipated pressure on the resource base. Many African countries are severely strained by these problems and as a result hard hit by immense demands from the international community, yet they lack the capacity to cope with these changes and where they do, it is negligible."

With regard to the Sudan, the United Nations Environment Programmee (2013) states that natural resource use is often subjected to conflicting needs. In this kind of situation the primary users such as farmers, pastoralists should have the greatest entitlement but unfortunately their interests are often ignored and subdued by powerful international business interests. This should not be. All over the continent there is poor environmental governance if not the interest of the poor, the disadvantaged and the local people should come first before others. But many governments in the continent often privilege the powerful. Agbese (2008) has shown that most African states are often not interested in environmental protection and they want to see environmental protection as a trade-off for development. The degrading state of many African urban environments is appalling. The cities are polluted with waste, traffic congestion, unplanned streets, etc. Oladipo, Okoya, Aladesanmi, and Ali (2011), Samita (2002), and Saghir \& Santoro (2018) have documented the poor management of urbanization. Hanson (2007) writes that: National governments and international aid organizations continue to privilege rural development. At the national level, many governments are loath to allocate resources to urban development and prefer to ignore growing urban areas. 'African governments and city officials need to step up to the plate,' says Mberu. 'They need to articulate that there are problems.' A few countries-including Nigeria, Kenya, and Uganda-are working to address urban growth. Burkina Faso, for instance, is working to improve transportation in its capital city, as well as strengthen the water 
and sewer system. Experts say local governments can now play a stronger role in the policy process due to the continent's broad movement toward political decentralization. In South Africa, for instance, a network of nine cities has developed to share information and develop strategies for good governance and city management.

Still on urbanization, Güneralp (2017) writes that:

Urban areas, growing both in population and in land cover, pose threats to the integrity of the continent's ecosystems and biodiversity but their growth also creates opportunities for conservation. The burgeoning urban populations, especially in Sub-Saharan Africa, increase the strain on already insufficient infrastructure and bring new governance challenges. Yet, Africa's ecosystems can serve as foundations for green infrastructure to serve the needs of its urban populations while safeguarding fragile biodiversity. Overall, while worsening social problems overshadow the concerns for biodiversity there are also promising initiatives to bring these concerns into the fold to address social, institutional, and ecological challenges that emerge with the continued urbanization of the continent.

Another area in which there is poor environmental governance in Africa is in regard to environmental sanitation. Environmental sanitation is often done from an anthropocentric angle without regard to other organisms in the ecosystems. Agbese (2008) has noted that environmental sanitation agents often misunderstand their works as removal of illegal structures and harassment of petty-traders. They seize good of poor and petty-traders and often take these goods as loot, even steal and get corrupted in the process. There is no adequate environmental education to educate citizens on their environmental obligations and duties.

\section{Grounding Environmental Governance in Environmental Ethics}

It would not be enough for government to make laws and policies to govern the environment in Africa. Those laws must be informed by an ethics that values not only humans but also natural systems, ecosystems, and other life forms in the continent. We need a non-anthropocentric ethics. While not neglecting the vital roles of humans in nature, and that they need to be fed and sustained from nature; it is important to restate that nature has intrinsic value. There has been a debate in environmental ethics whether nature should be conserved and protected for its own sake or it should be protected and conserved for the sake of humans.

What this paper argues for from an environmental pragmatic perspective is that for which ever reason it is done, it is imperative to conserve nature. If it is conserved it will serve both the wellbeing of humans and the natural environment. There are two predominant forms of environmental ethics. These two Curry (2006) names as "anthropocentric" meaning human-centered and "ecocentric" meaning earth-centered. For Curry (2006) under anthropocentric you have lifeboat ethics, light green ethics, animal liberation, animal rights and biocentric ethics; while the ecocentric ethics are the land ethic, Gaia theory, deep ecology, deep green theory, left biocentrism, the earth manifesto, ecofeminism, dogmatic secularism and ecocentric spirituality. For Smith (1997), there is environmental ethics of deep ecology, ecofeminism, animal rights, Leopoldian ethics, liberation ecotheology, the ecoethics of world religions, and that of the Catholic Magisterium. Deep ecology roots for ecological egalitarianism. Ecofeminism 
argues for moving from maltreatment of women, children, and the earth to developing positive attitudes to the oppressed earth. Leopoldian ethics affirms that behaviour is right or wrong depending on how it impacts the earth community. Liberation ecotheology emphasizes freeing the earth and the poor from ecological devastation motivated by religious values. The ecoethics of world religions sees the earth as sacred and valuable creature of God that needs to be protected. The ecoethics of the Catholic Magisterium puts emphasis on humans living in peace with all creation and living a life of stewardship as God's regent on earth.

Permit in this present paragraph to use the insights of Elliot (1995) to describe the two fundamental orientations in environmental ethics. It is true that human activities have modified nature and even destroyed ecosystems. These modifications include: "build-up of greenhouse gases, the depletion of the ozone layer, deforestation, land degradation, the elimination of species, and the pollution of the atmosphere and of rivers and oceans, threaten the well-being of both presently existing and future humans" (p.1). Human life and existence is totally dependent on nature. With the rise of environmentalism in western societies and elsewhere, there is a human-centered welfarist orientation to protect nature through prudence and concern and implementing policies to stop the devastation of the environment. Some environmental ethics affirm the rights of future generations and not just present generations. Utilitarian environmental ethics pays attention not to particular individuals whether they will exist in the future or not but to "the amount of happiness the future contains irrespective of the identity of those who experience it" (p.3). For the Utilitarianist the greatest net surplus of happiness in the future is what matters. The emphasis of virtue environmental ethics is on providing a "framework for condemning those human actions which degrade, spoil, or destroy the natural environment" (p. 4). With regard to ecofeminism, it is environmentalism informed by feminism and argues that despoliation of nature is a sign of the male capacity to care, nurture and lack of attention to aesthetic sensitivity. Using Plumwood's words, Elliot (1995) notes that ecofeminism states that in the western tradition nature is "sharply discontinuous from the human sphere" and this has caused much environmental damage. One of the innovative discoveries of environmental ethics is that environmental ethics and human behaviour towards nature should be centered on nature. Animal ethics moves for moving beyond unjustifiable human chauvinism in extending more consideration and concern to non-human animals. Other non-humans are also affected by human modification of natural environments and they have to capacity to feel pain and suffer. For Rolston, plants can be harmed and denied flourishing and so they need to be defended.

Environmental governance which implies the management and use of the resources of nature for the good of humans must move beyond anthropocentricism. The concern in environmental governance should not simply be on the use of resources for human wellbeing. There should be a move to emphasize protecting and conserving nature for the wellbeing of nature also. Even when aspects of nature are not useful today, they can be useful tomorrow. The animal care movement has emphasized the ethics of Peter Singer and Tom Reagan. Animals need to be protected from pain and suffering not just for human interests. It is inhumane to maltreat animals. There are many aspects of nature that are endangered today as a result of human actions. Non-human nature need 
to be protected and secured. Decisions and policies of government and all stakeholders in society should take into account the wellbeing of ecosystems and all life.

\section{Critical Evaluation: Towards Environmental Security Ethics}

The question of environmental governance which invariably implies environmental security is a very important one. Both human lives, properties, and other non-human beings and realities in nature are endangered. And these are ethical or moral issues. Millions of Africans are suffering and living in poverty in a continent that is blessed so much with natural wealth and resources. The lives of many are endangered and thousands are killed as a result of resource wars over the natural resources of the continent. This is an issue of human life. Human beings are entitled to their right to life, liberty and pursuit of happiness. They have a right to water, food, and other amenities of lives. When people die because of starvation and hunger in a continent that is so blessed, then it is wrong. It is inimical to the values found in African moral traditions that respect life and human dignity. It contravenes the values of Ubuntu (I am because we are), and Ujamaa (familyhood) and African humanism. . Environmental problems create serious security problems for society, and so environmental security should be at the top on the agenda of government.

It should be realized that conserving and protecting nature on the path of human governments, organizations and individuals is a moral obligation. It is a duty upon government. It is not something optional that governments have to embark upon. It is a priority for the peace and security of the citizens. If nature or the environment is not effectively governed and managed it will be subjected to vandalization and plundering from capitalist profiteers. These will endanger the lives of the people. Anthropogenic environmental problems caused by humans often cause flood, droughts, climate change, etc that affects people's lives. The United Nations in both the Millennium Development Goals and the Sustainable Development Goals emphasized the fact that the nations of the world have a duty to work for environmental protection. The United Nations have her agency, United Nations Environmental Programmee (UNEP). Matthai (2010) rightly states that there is a deep link between the environment and development, no true development can be achieved outside healthy ecosystems for what happens to the ecosystems affects everything" (p. 240). She writes that if the mountain ecosystem in Kenya is destroyed it affects energy supply, water supply, agriculture, tourism, etc. The government she says need to rise up to the challenge of managing the forest mountain ecosystem in a sustainable manner. Writing of the situation in Ethiopia, Matthai she states further that at the turn of the century, Ethiopia had $40 \%$ forest cover, but today, that is in 2010 it had only 3\% forest cover. This came as she notes from overgrazing, a cash crop economy, and use of wood for fuel.

In the light of all these there is need for environmental governance to be rooted in an environmental security ethics. By environmental security ethics the paper implies that environmental governance should focus on securing the environment. Government should see it as a moral obligation and aim to foster good behaviours towards nature, while working to eradicate destructive ecological behaviours. Feris (2010) rightly notes with regard to South Africa, environmental problems are also social problems as they 
directly affect humans, humans who may already be socio-politically disadvantaged. Feris (2010) because of this rightly argues that environmental governance should respond to environmental justice issues; and it is worthy to note that South African law has noted this in the National Environmental Management Act. Feris (2010) cites Section 2(4) (c) which states:'Environmental justice must be pursued so that adverse environmental impacts shall not be distributed in such a manner as to unfairly discriminate against any person, particularly vulnerable and disadvantaged persons." The point the paper is making is that this issue of environmental governance is a moral issue. The lives of the citizens cannot be secured fully if they are subjected to environmental harm and damage. It is important for government to pay attention then to environmental justice and racism. All through the continent, environmental pains and burdens are unequally distributed. Those who are poor and disadvantaged suffer more. Think of Nigeria's Niger Delta that suffers a great deal of environmental damage yet the great deal of profits goes to shareholders in western countries who never experience this pain of exploitation of oil. This is also what happens in place like Liberia, Sierra Leone, Democratic Republic of Congo, Angola, etc.

It ought to be recognized that human rights are moral issues. Government and other stakeholders have a duty and responsibility to respond to and safeguard them. It is worth noting that national constitutions or human rights instruments have all endorse the reality of people's right to environmental protection. The South African (1996) in Section 24 of her Constitution states thus:

Everyone has the right - (a) to an environment that is not harmful to their health or wellbeing; and (b) to have the environment protected, for the benefit of present and future generations, through reasonable legislative and other measures that - (i) prevent pollution and ecological degradation (ii) promote conservation; and (iii) secure ecologically sustainable development and use of natural resources while promoting justifiable economic and social development.

What you find in the South African Constitution you will find in many other constitutions in Africa. What is argued for in this paper is environmental governance that is informed and permeated by non-anthropocentric environmental ethics. Effective environmental governance will enhance environmental security which in turn will enhance overall security of every society and Africa. Such ethics is thoroughly grounded on the earth not simply the values of capitalist business or the wellbeing of humans. Africa needs environmental security ethics that sees the good of the public and the goals of government as only totally meaningful only when they are for the good of all earth communities. This kind of ethics can be described in the words of Rolston (2012) who opines thus:

The Earth story is the larger history to which we human also belong, along with the myriads of creatures great and small. Evolutionary natural history has generated humans too, and global ecology still supports us. This is a concern about resources, but it is more than that. It is a concern about our sources past, our story continuing, our future entwined with the planet's future. Our identity is cultural, culturally specific, yes but our identity is also flesh and blood, emplaced in the array of metabolic processes in which we are set: web works of ecosystems, trophic pyramids, photosynthesis, plant geography, soils, weathers and climates, the perennial cycling and re-cycling of water, oxygen, carbon dioxide, the geo-solar ecology and economy. Earth is not simply the stage, but the story. 
In that sense we do not just want sustainable development, maximum exploitation of earth's resources, but a sustainable biosphere, because we are incarnate in that biosphere. We are Earthlings. Our integrity is inseparable from Earth integrity. (p. 220)

The above is what the paper is arguing for, that governance, government, organizations and the way humans carry out their activities should be done in such a way to enhance the flourishing of the planet, not its degradation. It is true that human activities will moderate the earth but it should be done in such a way that there is minimal damage and the earth is allowed to flourish.

\section{Conclusion}

This paper agrees with the sentiments of Agbese (2009) who argues as follows:

African states can no longer afford to ignore the continent's environmental crisis. First, it is now apparent that Africa is experiencing many forms of environmental strains and stresses. Environmental problems such as industrial pollution, uncontrolled discharge of industrial wastes, deforestation and other depletions of natural resources, oil pollution, soil erosion and desert encroachment are increasing at alarming rates. Second, the costs associated with these problems are getting prohibitively expensive. Third, as mentioned earlier, the post-colonial governments thought that they had made a necessary trade-off between economic development and environmental degradation but the stark reality by the 1990s was that Africa had not made any economic advancement that could compensate for the horrendous environmental despoliation caused by developmental activities. African did not grow as rapidly as expected. In places where economic growth did occur, it most often had negative consequences on the environment and people. (p. 190-191)

African must rise to the challenge of environmental governance and conservation of the earth more than ever before. When there is healthy environmental governance it has dividends for all other aspects of individual and public life. Let the work of promoting a healthy environmental governance and security ethics begin/continue now for an environmentally sustainable Africa.

\section{References}

Agbese, P.O. (2008). The state and the environment in Africa. In George Klay Kieh and Pita Ogaba Agbese (Ed.), The state in Africa: Issues and perspectives (pp.185-207). Ibadan: Kraft Books.

Curry, P. (2006). Ecological Ethics: An introduction. Cambridge: Polity Press.

DesJardins, J.R. (2006). Environmental Ethics; An introduction to Environmental Philosophy.

Boston, MA: Wadsworth.

Elliot, R. (1995). Environmental Ethics. Oxford: Oxford University Press.

Fage, K.S. (2007). Nigeria's national security in the $21^{\text {st }}$ century: The need for a realistic

re-assessment of national defence policy and strategic intelligence. In Ozemenam

Mbachu and Momoh Lawani Yesufu (Ed.), Contemporary Strategic Studies (pp119-142).

Kaduna: Medusa Academic Publishers.

Feris, L.A. (2010). The role of good environmental governance in the sustainable development of South Africa. Retrieved July 10, 2020,

from http://www.scielo.org.za/scielo.php?script=sci arttext\&pid=S1727- 37812010000100003

Güneralp, B. (2017). Urbanization in Africa: challenges and opportunities for conservation. Retrieved July 20, 2020, from https://iopscience.iop.org/article/10.1088/1748-9326/aa94fe 
Hanson, S. (2007). Urbanization in Sub-Saharan Africa. Retrieved July 20, 2020, from https://www.cfr.org/backgrounder/urbanization-sub-saharan-africa

Institute for Security Studies. (2009). Achieving effective national environmental governance

in Africa. Retrieved July 10, 2020, from https://issafrica.org/iss-today/achieving-effective-nationalenvironmental- governance-in-africa.

Institute of Governance. (2019). Defining governance. Retrieved July 20, 2020,

from https://iog.ca/what-is-governance/

International Union for Conservation of Nature. (2019). Governance and MEAs. Retrieved July 20, 2020, from https://www.iucn.org/theme/environmental-law/our-work/governance-and-meas

Maathai, W. (2010). The challenge of Africa. London: Arrow Books.

Micheals, F. (2004). Lotus illustrated dictionary of environmental studies. New Delhi: Lotus Press.

Ramutsindela, M., \& Büscher, B. (2019). Environmental governance and the (re-)making of the African State.

Retrieved July 20, 2020, from doi: 10.1093/acrefore/9780190228637.013.903

Ribot, J., \& Veit, P. (2001). Environmental governance in Africa. Retrieved July 20, 2020, from https://www.wri.org/publication/environmental-governance-in-africa-series

Rolston, H. (2012). A new Environmental Ethics: The next millennium for life on earth. New York: Routledge. . (1988). Environmental Ethics. Philadelphia: Temple University Press.

Samita, Z.W. (2002). African cities and environmental challenges. In Mary N Getuo and Matthew M. Theuri (Ed.), Quest for abundant life in Africa (pp. 175-186). Nairobi, Kenya: Acton Publishers.

Obi. C. (2001).Globalized images of environmental security in Africa. In R. A. Akindele and Bassey E Ate (Ed.), Beyond conflict resolution: Managing African security in the 21st Century (pp. 168-186). Ibadan: Vintage Publishers.

Oladipo, O.G., Okoya, A.A., Aladesanmi, O.T., \& Ali, G.A. (2011). Policy direction for municipal public waste in Nigeria. In Ayoabami T Salami and Oluwagbenga O.I. Orimoogunje (Ed.), Environmental research and challenges of sustainable development in Nigeria (pp. 569-584). Ile-Ife: Obafemi Awolowo University Press.

Organization of African Unity. (1981). African Charter on Human and Peoples' Rights. Retrieved July 20, 2020, from http://www.achpr.org/instruments/achpr\#a24

Saghir, J., \& Santoro, J. (2018). Urbanization in Sub-Sabaran Africa: Meeting challenges by bridging stakeholders. Retrieved July 20, 2020, from

https://www.csis.org/analysis/urbanization-sub-saharan-africa

Schweitzer, A. (1949). Out of my life and thought: An autobiography. New York: Holt, Rinehart \& Winston.

Smith, P. (1997). What are they saying about Environmental Ethics? New York: Paulist Press.

South Africa. (1996). The Constitution of South Africa. Retrieved July 20, 2020, from https://www.gov.za/documents/constitution/constitution-republic-south-africa-1996-1

Tamayao, M. J. M. (2019). What is governance? Retrieved July 20, 2020, from https://tamayaosbc.wordpress.com/2014/08/21/what-is-governance/

United Kingdom. (1990). Environmental Protection Act. Retrieved July 10, 2020, from https://www.legislation.gov.uk/ukpga/1990/43/contents

United Nations. (2007). Universal Declaration on the Rights of Indigenous Peoples. New York: United Nations.

United Nations Environment Programmee. (2013). Governance for peace over natural resources: A review of transitions in environmental governance across Africa as a resource for peacebuilding and environmental management in Sudan. Retrieved July 10, 2020, from

https://postconflict.unep.ch/publications/sudan/UNEP Sudan Governance for peace 2013.pdf 